\title{
ROZWÓJ KARIERY ZAWODOWEJ WŚRÓD PRZEDSTAWICIELI POKOLENIA X I Y - NOWE WYZWANIA
}

Dynamiczne zmiany, jakie obserwujemy na rynku pracy, i towarzyszące im zmiany struktury zatrudnienia, zanikanie starych zawodów i powstawanie nowych stanowią nowe wyzwania dotyczące kształtowania kariery zawodowej zarówno dla pracowników, jak i pracodawców. Tradycyjny model kariery zawodowej rozumianej często jako etat na całe życie należy już do przeszłości, a wymogiem czasu jest ciagle uczenie się i przekwalifikowanie w celu budowania kapitału kariery i zwiększania swojej indywidualnej zdolności do bycia zatrudnionym.

Obecnie karierę zawodową wyznacza trend uczenia się i rozwoju przez całe życie. Wymaga to nowego podejścia do kariery zawodowej jako projektu życiowego i determinuje stworzenie warunków, w których każdy człowiek miałby łatwy dostęp do rzetelnych informacji o rynku pracy. Ponadto na rynku pracy obserwuje się duże zróżnicowanie grup wiekowych pracowników, co skutkuje znacznymi różnicami pokoleniowymi występującymi także w przejawianych postawach zarówno wobec pracy, jak i kariery zawodowej.

Celem niniejszego artykułu będzie wskazanie nowych wyzwań w podejściu do własnej kariery zawodowej wśród przedstawicieli pokolenia X i Y (pokolenie X, czyli osoby urodzone w latach 1965-1980, natomiast pokolenie Y stanowią młodzi ludzie urodzeni po roku 1980).

W artykule zawarto prezentację wyników badań i opinii pracowników dolnośląskich przedsiębiorstw (przedstawicieli pokolenia $\mathrm{X}$ i Y) oraz studentów i absolwentów Uniwersytetu Ekonomicznego we Wrocławiu (przedstawicieli pokolenia Y) dotyczących prezentowanego zagadnienia.

Słowa kluczowe: kariera zawodowa, pokolenie X, pokolenie Y.

\section{WPROWADZENIE}

Współczesny rynek pracy charakteryzuje z jednej strony nadmiar nieprzydatnych już kompetencji, a $\mathrm{z}$ drugiej duże braki w zakresie nowych umiejętności i doświadczeń. Powoduje to pojawienie się znacznej luki kompetencyjnej, której eliminacja stanowi duże wyzwanie zarówno dla systemu edukacji, jak i potencjalnych pracowników poszukujących swojej ścieżki kariery zawodowej.

Według Stelli Molitor ${ }^{2}$ stałe miejsca pracy z dokładnie ustalonym zakresem zadań stopniowo znikają. Każdego roku ubywa około $10 \%$ wszystkich miejsc pracy, a w ich miejsce pojawiają się nowe zawody wymagające innych lub znacznie szerszych kompetencji. Zmienia się też charakter kontraktu psychologicznego, w którym nie ma już obietnic stałego zatrudnienia.

\footnotetext{
${ }^{1}$ Dr inż. Alicja Smolbik-Jęczmień, Katedra Zarządzania Produkcją i Pracą, Wydział Zarządzania Informatyki i Finansów, Uniwersytet Ekonomiczny we Wrocławiu, 58-100 Świdnica, ul. Wałbrzyska 60, alicja.smolbik@ue.wroc.pl.

2 S.U. Molitor, Strategia planowania kariery, BC Edukacja, Warszawa 2008, s. 47-48.
} 
Niewątpliwie starsze pokolenie pamięta jeszcze czasy, w których pracownicy często zmieniający swoją pracę byli źle postrzegani przez przyszłych pracodawców i mieli duże trudności ze znalezieniem stałego zatrudnienia. Uważano ich wręcz za osoby niemające zdolności adaptacyjnych, ciągle niezadowolone z pracy, które nie wiedzą, czego oczekują od życia. Obecnie częste zmiany miejsc pracy, zawodu czy specjalności stają się coraz bardziej powszechne, a tradycyjne ujęcie kariery jako pracy w jednej czy dwóch firmach aż do osiagnięcia wieku emerytalnego należy już w zasadzie do przeszłości ${ }^{3}$.

Otwarcie rynków pracy zarówno w Europie, jak i na świecie stwarza nowe szanse i możliwości szczególnie przed dobrze wykształconymi, młodymi ludźmi, dla których mobilność zarówno w wymiarze geograficznym, jak i psychologicznym nie stanowi istotnego problemu.

Obecnie karierę zawodową wyznacza trend uczenia się i rozwoju przez całe życie. Coraz rzadziej istnieje możliwość wybrania jednego zawodu na całe życie. Wymaga to podejścia do kariery zawodowej jako projektu życiowego i determinuje stworzenie warunków, w których każdy człowiek miałby łatwy dostęp do rzetelnych informacji o rynku pracy. Ponadto trudna sytuacja absolwentów na rynku pracy stawia również duże wyzwania wobec wyższych uczelni, które powinny aktywnie uczestniczyć w procesie przygotowania studentów i absolwentów do funkcjonowania w nowej rzeczywistości ${ }^{4}$.

Skutkuje to więc istotnymi zmianami w podejściu do życia i kształtowania kariery zawodowej szczególnie przez przedstawicieli pokolenia X i Y. Wymogiem czasu staje się nieustanne doskonalenie posiadanych już umiejętności i zdobywanie nowych potrzebnych na rynku pracy kompetencji, a także budowanie swojej tożsamości profesjonalnej, czyli kapitału kariery, a także głęboka refleksja dotycząca realnej oceny swoich szans zawodowych na dynamicznie zmieniających się rynkach.

Celem niniejszego artykułu będzie wskazanie nowych wyzwań w podejściu do własnej kariery zawodowej wśród przedstawicieli pokolenia X i Y, a w szczególności prezentacja wyników badań i opinii pracowników dolnośląskich przedsiębiorstw oraz studentów i absolwentów Uniwersytetu Ekonomicznego we Wrocławiu dotyczących prezentowanego zagadnienia. Artykuł oparty jest na studiach literaturowych oraz na badaniach ankietowych i wywiadach bezpośrednich.

\section{WSPÓŁCZESNE POJECCIE KARIERY ZAWODOWEJ}

Przemiany, jakie dokonują się we współczesnym świecie, stwarzają nowe wyzwania odnośnie do kształtowania kariery zawodowej zarówno dla pracowników, jak i pracodawców. Tradycyjny model kariery, opierający się na rozwijaniu i wykonywaniu wyuczonego zawodu najczęściej w jednej firmie aż do osiagnięcia wieku emerytalnego, to już przeszłość. Dokonujące się przeobrażenia w sferze karier zawodowych polegają na przebudowie relacji między jednostką i organizacją z zależnościowych na podmiotowe, co skutkuje przesunięciem odpowiedzialności za kształt i przebieg kariery w stronę jednostki jako jej głównego realizatora 5 .

A. Miś, Koncepcja rozwoju kariery zawodowej w organizacji, UE, Kraków 2007, s. 476-479.

4 A. Smolbik-Jęczmień, Nowe trendy w podejściu do kariery zawodowej wśród przedstawicieli pokolenia $Y$, [w:] Osobowościowe i kompetencyjne uwarunkowania sukcesu, red. A. Barabasz, E. Głuszek, Prace Naukowe Uniwersytetu Ekonomicznego we Wrocławiu, Wrocław 2012/273, s. 96.

5 P. Bohdziewicz, Kariery zawodowe w gospodarce opartej na wiedzy (na przyktadzie grupy zawodowej informatyków), Wydawnictwo Uniwersytetu Łódzkiego, Łódź 2008. 
Współcześnie zarządzanie karierą należy pojmować jako całościowy proces pomagający pracownikom odnaleźć swoje miejsce na trudnym i złożonym rynku pracy oraz wskazujący, jak dostosować preferencje i zdolności do pojawiających się na tym rynku różnych okazji i szans. Ciągła adaptacja pracowników do nowych wymogów rynku pracy, otwartość na nowe trendy, gotowość zmiany zawodu lub całkowite przeorientowanie swojej dotychczasowej kariery to tylko niektóre z istotnych aspektów świadczących o akceptacji nowego podejścia do rozwoju i zarządzania swoją karierą.

W nowym rozumieniu kariery lojalność pracownika w stosunku do organizacji zostaje zastąpiona lojalnością profesjonalną $w$ ramach wykonywanego zawodu, następuje też przeorientowanie się z nagród zewnętrznych bardziej w kierunku nagród wewnętrznych oraz ponoszenie bezpośredniej odpowiedzialności przez pracownika za przebieg własnej kariery zawodowej ${ }^{6}$.

Współczesne kariery zawodowe charakteryzuje duży stopień nieprzewidywalności, co znacznie zwiększa wymagania przed jej realizatorami. W szczególności dotyczy to posiadania indywidualnej zdolności do bycia zatrudnionym na podstawie szerokich kompetencji zawodowych, sieci kontaktów, a także autopromocji na zewnętrznym rynku pracy. Drugim warunkiem realizacji nowej kariery jest posiadanie spójnej tożsamości profesjonalnej, wynikającej z wcześniejszych doświadczeń zawodowych jednostki, a nie tylko z przynależności do organizacji, jak w tradycyjnej karierze ${ }^{7}$.

Budowanie kapitału kariery wymaga więc od każdej jednostki umiejętności samokierowania i wyznaczania celów, zdolności do skutecznego komunikowania się ze wszystkimi, budowania i podtrzymywania osobistych i zawodowych relacji, myślenia kreatywnego i działania proaktywnego, a także ustawicznego kształcenia i doskonalenia.

Według autorki obecnie kariera zawodowa stanowi proces rozwoju wiedzy i umiejętności, kształtowania postaw, cech osobowych, systemu wartości i motywacji jednostki w celu zwiększania swojej wartości na rynku pracy i zapewnienia zatrudnialności.

W trakcie kariery nabywane są unikatowe doświadczenia dzięki pracy w różnych organizacjach, poprzez wykonywanie różnych zawodów i pełnienie funkcji zgodnie z realizacją własnych predyspozycji, oczekiwań i aspiracji dających jednostce poczucie wewnętrznej satysfakcji i spełnienia zarówno zawodowego, jak i życiowego. Ponadto wszelkie działania jednostki powinny być dostosowane do wymogów dynamicznie zmieniającego otoczenia. Aby proces ten mógł się rozwijać we właściwym kierunku, jednostka powinna posiadać „,energię kariery”, czyli siłę, chęć i motywację do dalszego doskonalenia się i rozwoju, by móc w pełni realizować swoje pasje i zainteresowania podczas aktywności zawodowej i życiowej.

Aktualnie zaczynają funkcjonować nowe wymiary kariery wychodzące poza przestrzeń organizacyjną jednego pracodawcy czy nawet kraju, określane mianem „karier bez granic ${ }^{8}$ ". Charakteryzują się one transakcyjnością i krótkoterminowością, a jednostka negocjuje swoje warunki zatrudnienia $\mathrm{z}$ daną organizacją we właściwy sobie sposób, kierując się przy tym samodzielnością oraz posiadanymi zdolnościami i umiejętnościami.

\footnotetext{
6 W. Lanthaler, J. Zugmann, Akcja Ja, nowy sposób myślenia o karierze, Twigger, Warszawa 2000, s. 28-32.

P. Bohdziewicz, op. cit.

8 M. Rybak, Kariery bez granic. Nowe spojrzenie na karierę zawodowq, [w:] Zarzqdzanie zasobami ludzkimi w przedsiębiorstwie, red. M. Rybak, Wydawnictwo SGH, Warszawa1998, s. 334.
} 


\section{OGÓLNA CHARAKTERYSTYKA POKOLENIA X I Y}

Obecnie na rynku pracy obserwuje się duże zróżnicowanie grup wiekowych pracowników, co stanowi duże wyzwanie dla menedżerów oraz skutkuje znacznymi różnicami pokoleniowymi występującymi także w przejawianych postawach zarówno wobec pracy, jak i kariery zawodowej.

W Polsce za podstawową linię podziału między pokoleniami uważa się osoby urodzone przed 1980 r. i po nim. Należy jednak podkreślić, że nie są to grupy jednorodne. I tak w pierwszej z nich wyróżnia się pokolenie $50+\mathrm{i}$ pokolenie $\mathrm{X}$, czyli osoby urodzone w latach 1965-1980, natomiast drugą grupę stanowią młodzi ludzie urodzeni po roku 1980, czyli pokolenie $\mathrm{Y}^{9}$.

Ze względu na ograniczone ramy opracowania w niniejszym artykule skupiono się na analizie dwóch ostatnich generacji, a mianowicie pokolenia X i Y.

Pokolenie $\mathrm{X}$ to osoby, które wkraczały w dorosłość w okresie kryzysu ekonomicznego lat siedemdziesiątych. Wiedzą, że droga do sukcesu zawodowego wymaga nie tylko doskonałego wykształcenia i kompetencji, ale dużego zaangażowania i poświęceń. Dla pokolenia X praca stanowi wartość samą w sobie. Często określa się to pokolenie stwierdzeniem: „Żyją po to, żeby pracować”. W większości preferują tradycyjne podejście do kariery, potrafią też wytrwale czekać na awans i nie upominają się za często o podwyżki. Rozwijają swoje zainteresowania i pasje, ale nie kosztem pracy ${ }^{10}$.

Natomiast pokolenie Y szczególnie ceni sobie pracę, która stanowi dla niego realizacje pasji i zainteresowań oraz umożliwia dalszy rozwój i zachowanie równowagi praca-życie. Mówi się o nich: „Pracują po to, żeby żyć”. Pokolenie to jest często określane jako bardzo roszczeniowe i nadmiernie przeceniające swoje umiejętności ${ }^{11}$.

Ogólną charakterystykę pokolenia X i Y przedstawiono w tabeli 1.

Tabela 1. Charakterystyka pokolenia X i Y

\begin{tabular}{|c|c|c|}
\hline Wyszczególnienie & Pokolenie X & Pokolenie Y \\
\hline Cecha dominująca & $\begin{array}{l}\text { Sceptycyzm, pesymiści } \\
\text { pozbawieni złudzeń }\end{array}$ & $\begin{array}{l}\text { Realizm, ciekawość świata, } \\
\text { poczucie wolności }\end{array}$ \\
\hline $\begin{array}{l}\text { Ogólna } \\
\text { charakterystyka }\end{array}$ & $\begin{array}{l}\text { Zainteresowanie innowacyjnością } \\
\text { i wyzwaniami przedsiębiorstwa, } \\
\text { ale na podstawie twardych } \\
\text { danych, lojalni wobec } \\
\text { pracodawcy, często pracoholicy, } \\
\text { duża etyka pracy, nie bardzo } \\
\text { pewni siebie i swojej wartości, } \\
\text { nie lubią hierarchii, ale uznają } \\
\text { autorytet przełożonych, }\end{array}$ & $\begin{array}{l}\text { Zamknięcie w świecie } \\
\text { różnorodnych mediów } \\
\text { i eksperymentalnego uczenia się, } \\
\text { wysoka świadomość swojej } \\
\text { wartości, duża podzielność uwagi, } \\
\text { mniej lojalni wobec pracodawcy, } \\
\text { często nie uznają autorytetu } \\
\text { przełożonego - liczą się jego } \\
\text { kompetencje, oczekują }\end{array}$ \\
\hline
\end{tabular}

\footnotetext{
9 A. Zagórowska, Konflikt generacyjny wokót pracy, [w:] Perspektywy młodzieży. Młodzież w perspektywie. Region - Polska - Europa - Świat, Część I: Mtodzież a edukacja i rynek pracy, red. A. Zagórowska, Wydawnictwo Politechnika Opolska, Opole 2012, s. 15.

${ }^{10}$ L. Weroniczak, Człowiek w obliczu szybko dokonujacych się zmian, [w:] Bo życie to nieustanny rozwój. Poradnik, red. J. Majerowska, Edustacja.pl, Poznań 2010, s. 40-42.

11 J. Czapiński, Młodzi Polacy na progu dorostości - czy dadzq sobie radę?, Materiały konferencyjne, „Generacja Y - szansa czy konflikt”, GM Solutions, Warszawa 2012.
} 


\begin{tabular}{|l|l|l|}
\hline & $\begin{array}{l}\text { potrzebują wsparcia zespołów i } \\
\text { poczucia przydatności }\end{array}$ & elastyczności w pracy \\
\hline Cel kariery & $\begin{array}{l}\text { Potrafią cierpliwie czekać na } \\
\text { awans czy podwyżkę, kariera } \\
\text { „przenośna” }\end{array}$ & $\begin{array}{l}\text { Oczekiwanie szybkiej kariery, } \\
\text { kariery ,równoległe”, kariery bez } \\
\text { granic }\end{array}$ \\
\hline $\begin{array}{l}\text { Oczekiwana } \\
\text { gratyfikacja }\end{array}$ & $\begin{array}{l}\text { Motywację czerpią z poczucia } \\
\text { satysfakcji i zadowolenia z pracy, } \\
\text { wysokiej pozycji i prestiżu }\end{array}$ & $\begin{array}{l}\text { Szybko i dobrze płatna praca, } \\
\text { oczekiwania dotyczące rozwoju, } \\
\text { kreatywności i otwartości w pracy }\end{array}$ \\
\hline $\begin{array}{l}\text { Równowaga praca- } \\
\text { życie }\end{array}$ & $\begin{array}{l}\text { Potrzeba równowagi, ale dopiero } \\
\text { na emeryturze, często występuje } \\
\text { pracoholizm i wypalenie } \\
\text { zawodowe }\end{array}$ & $\begin{array}{l}\text { Praca nie jest wszystkim, duża } \\
\text { potrzeba elastyczności i równowagi } \\
\text { praca-życie }\end{array}$ \\
\hline Zmiana pracy & $\begin{array}{l}\text { Jest koniecznością, lęk przed } \\
\text { utratą osiagniętych pozycji }\end{array}$ & $\begin{array}{l}\text { Jest codziennością - duża } \\
\text { mobilność zawodowa, łatwość } \\
\text { adaptacji, otwartość na zmiany }\end{array}$ \\
\hline Szkolenia i rozwój & $\begin{array}{l}\text { Szkolenia traktowane jako } \\
\text { kotwica zatrudnienia }\end{array}$ & $\begin{array}{l}\text { Kształcenie ustawiczne jest } \\
\text { sposobem na życie }\end{array}$ \\
\hline
\end{tabular}

Źródło: opracowano na podstawie: J. Czapiński, Młodzi Polacy na progu dorostości - czy dadza sobie radę?, Materiały konferencyjne, Generacja $Y$ - szansa czy konflikt, GM Solutions, Warszawa 2012; A. Zagórowska, Konflikt generacyjny wokót pracy, [w:] Perspektywy młodzieży. Młodzież w perspektywie. Region - Polska - Europa - Świat, Część I: Młodzież a edukacja $i$ rynek pracy, red. A. Zagórowska, Wydawnictwo Politechnika Opolska, Opole 2012, s. 16-17; L. Weroniczak, Człowiek $w$ obliczu szybko dokonujacych się zmian,[w:] Bo życie to nieustanny rozwój. Poradnik, red. J. Majerowska, Edustacja.pl, Poznań 2010, s. 40-42.

Do słabych stron pokolenia Y należy przekonanie, że jeśli czegoś nie ma w sieci, to taka rzecz nie istnieje - ogranicza to ich zdolność rozwiązywania problemów. Ponadto nauczeni biegłego posługiwania się klawiaturą, często zapominają, jak się pisze ręcznie. Zdobycze technologii, z których tak aktywnie korzystaja, pozostawiają im mało czasu na myślenie autonomiczne i wyrobienie sobie własnych poglądów. Nie szukają autorytetów, żyjąc w przekonaniu, że „wszystko jest w ich rękach” i nikt nie może im nic narzucić. Często też są zbyt pewni siebie i niecierpliwi, dlatego muszą się dopiero uczyć odpowiedzialności za swoje czyny ${ }^{12}$.

Dlatego też aby wyzwolić motywacje ,igreków”, przełożeni powinni wyznaczać im zadania krótkoterminowe i bezpośrednio po ich realizacji dokonywać ich oceny oraz przekazywać informacje zwrotną wraz z należnymi gratyfikacjami zarówno finansowymi, jak i pozafinansowymi. Ponadto wskazane jest wykorzystanie ich zdolności do szybkiego uczenia się i wielozadaniowości, umiejętności jednoczesnego wykonywania wielu rzeczy. Młodzi ludzie potrafią prowadzić kilka procesów równocześnie, wiedzą też, jak korzystać z najnowszych technologii i wszelkich możliwości, jakie stwarza dana organizacja, przyczyniając się tym samym do jej efektywności.

Jak wskazują wyniki badań przeprowadzone przez firmę GMS, przedstawiciele pokolenia Y mają $\mathrm{w}$ większości wyższe wykształcenie $-47,2 \%$, biegłą znajomość języków obcych $-54,2 \%$ oraz są bardziej mobilni zawodowo niż ich starsi koledzy

${ }^{12}$ E. Chester, Młodzi w pracy. Jak zadbać o pracowników pokolenia Y, Helion, Gliwice 2007, s. 33-34. 
pokolenia X. Jednakże mają większe trudności ze znalezieniem pracy, szczególnie ze względu na brak doświadczenia zawodowego i niekiedy wygórowanie aspiracje i oczekiwania wobec pracy ${ }^{13}$. Ponadto przedstawiciele pokolenia Y dążą do uzyskania szybkiego awansu oraz oczekują pracy, która gwarantowałaby im większą niezależność, długi urlop czy dogodne godziny pracy. Priorytetowe znaczenie ma dla nich możliwość rozwoju osobistego (rys. 1).

Rys. 1. Najważniejsze sprawy w pracy zawodowej dla pokolenia X i Y

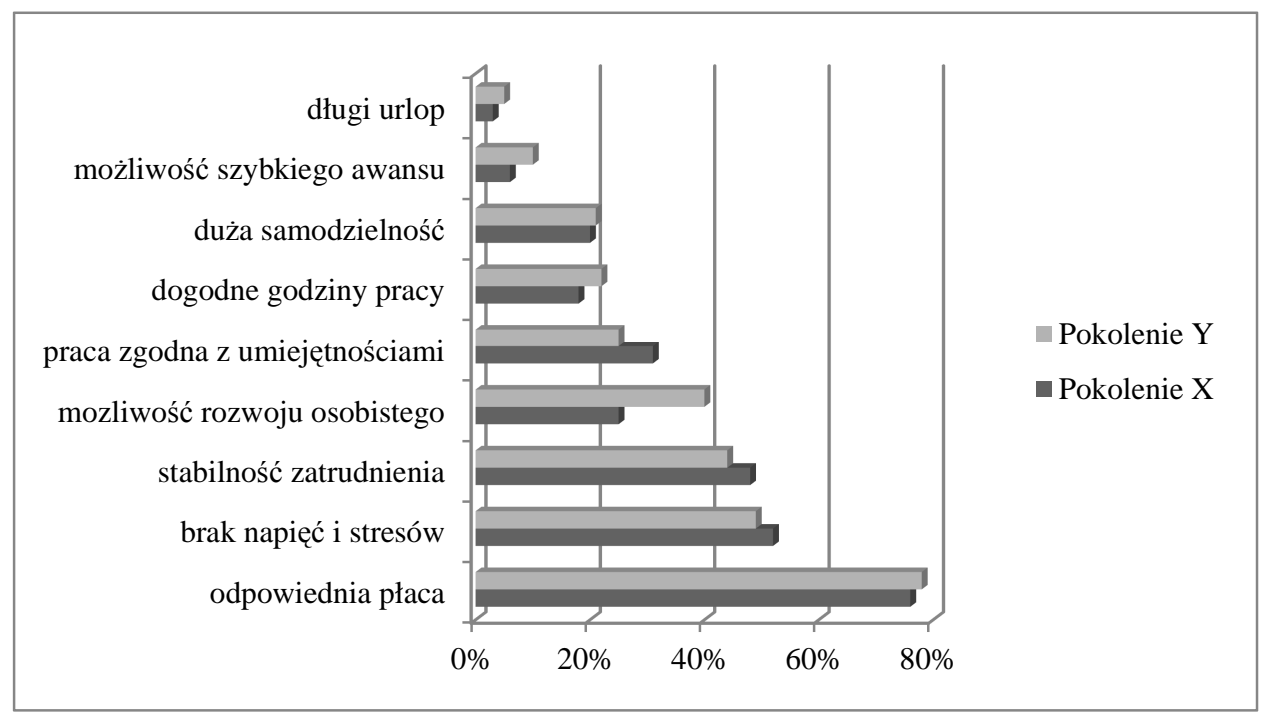

Źródło: opracowano na podstawie: M. Boni, Raport Młodzi 2011, KPRM, Warszawa 2011, s. 21.

Nie zauważa się istotnych różnic pokoleniowych w odniesieniu do pozostałych oczekiwań zawodowych - zarówno dla pokolenia X, jak i Y najbardziej liczą się wynagrodzenie, bezstresowa praca, stabilność zatrudnienia, a także duża samodzielność w pracy.

\section{PREZENTACJA WYNIKÓW BADAŃ}

Autorka przeprowadziła badania ankietowe i wywiady bezpośrednie dotyczące podejścia do kariery zawodowej wśród przedstawicieli pokolenia X i Y - pracowników dolnośląskich firm i pokolenia Y - studentów i absolwentów Uniwersytetu Ekonomicznego we Wrocławiu.

Badania wśród pracowników przedsiębiorstw Dolnego Śląska przeprowadzano w latach 2012-2013, a udział w nich wzięło łącznie 124 osoby, z czego do pokolenia X (z przedziału wiekowego powyżej 36 lat) należało 56 osób, a do pokolenia $\mathrm{Y}-68$ osób ${ }^{14}$.

\footnotetext{
${ }^{13}$ J. Czapiński, op. cit.

${ }^{14}$ Badani pracownicy dolnośląskich firm byli jednocześnie studentami Studiów Podyplomowych Zarządzania Pracą i Zarządzania Produkcją i Usługami organizowanych przez Uniwersytet Ekonomiczny we Wrocławiu.
} 
Ze względu na ograniczoną objętość artykułu zaprezentowano jedynie wycinek badań związany bezpośrednio z tematyką niniejszego artykułu.

Ankietowani mieli odpowiedzieć na pytanie, jak w obecnych warunkach postrzegają karierę zawodową. Jak wynika z przeprowadzonych badań, prawie $82 \%$ respondentów przedstawicieli pokolenia $\mathrm{X}$ - traktowało karierę nadal w sposób tradycyjny, utożsamiając ją przede wszystkim $\mathrm{z}$ awansem pionowym i zajmowaniem coraz wyższych stanowisk w hierarchii organizacji. Jednakże na pozytywną uwagę zasługuje fakt, że dla 62\% respondentów kariera zawodowa wiąże się z ciągłym procesem doskonalenia posiadanych kompetencji - co już jest przejawem nowego sposobu myślenia o karierze (rys. 2).

Za ważne w kształtowaniu kariery zawodowej przedstawiciele pokolenia X uznali również osiąganie satysfakcji i zadowolenia z pracy (67\% respondentów) oraz dążenie do zachowania równowagi między pracą zawodową a życiem osobistym (32\%).

Rys. 2. Postrzeganie kariery zawodowej przez przedstawicieli pokolenia X i Y

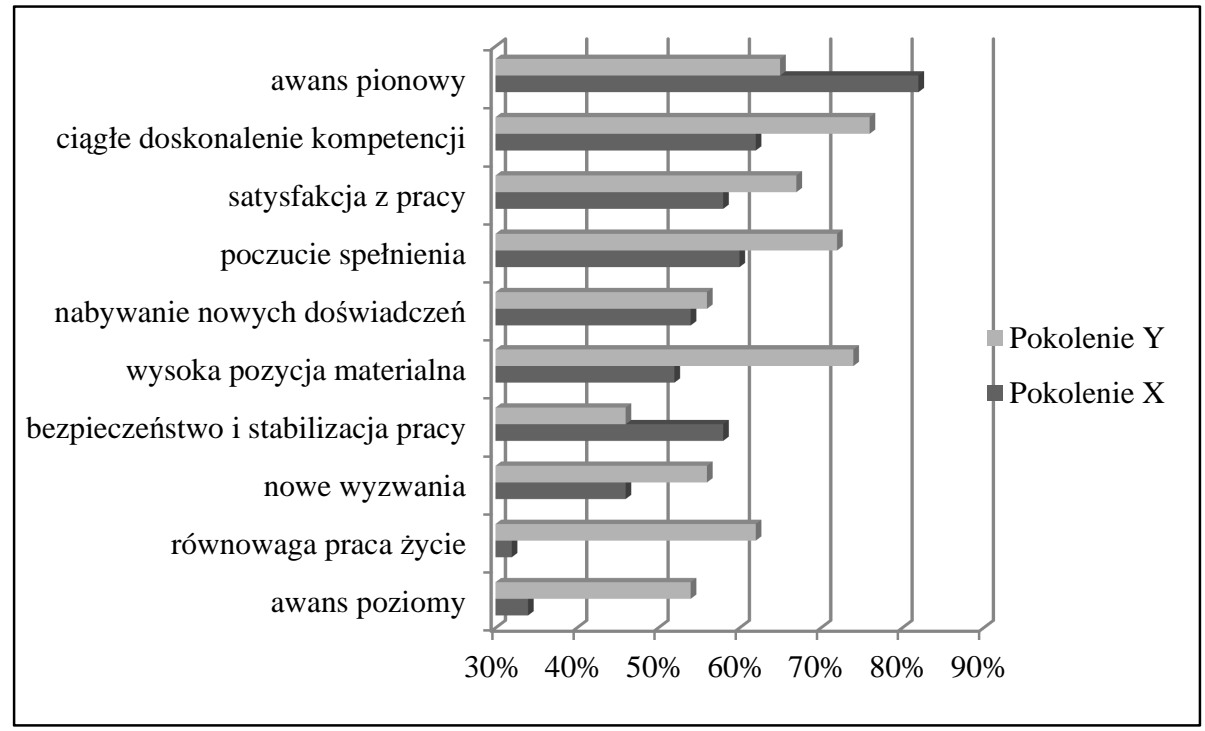

Źródło: opracowanie własne na podstawie przeprowadzonych badań ankietowych (odsetki nie sumują się do $100 \%$, ponieważ respondenci mieli możliwość wielokrotnego wyboru).

Przejawiane oczekiwania wobec pracy badanych przedstawicieli pokolenia $\mathrm{X}$ wskazują, że tradycyjne wyznaczniki kariery zawodowej (poza awansem pionowym), takie jak możliwości uzyskiwania wysokiego wynagrodzenia czy bezpieczeństwo pracy, znajdują się na dalszych pozycjach.

Można więc sądzić, że badani przedstawiciele pokolenia X rozumieją konieczność odejścia od tradycyjnego modelu kariery i sami dążą do wzmacniania swojej pozycji na rynku pracy. Należy jednak zaznaczyć, że badani stanowili specyficzną grupę - byli nie tylko pracownikami, lecz jednocześnie studentami studiów podyplomowych, którzy $\mathrm{z}$ reguły wykazują bardzo aktywne podejście do własnego rozwoju zawodowego. 
Natomiast badani przedstawiciele pokolenia $\mathrm{Y}$ z dolnośląskich firm mieli bardziej nowoczesne podejście do kariery zawodowej. Uważali, że aby osiagnnąć sukces zawodowy i zrealizować wymarzoną karierę, najważniejsze jest ciągłe doskonalenie posiadanych kompetencji (76\%). Wskazywali także na duże znaczenie poczucia spełnienia i satysfakcji z pracy $(72 \%)$ oraz możliwość zachowania równowagi praca-życie. Jedynie chęć uzyskania wysokiej pozycji materialnej, za którą opowiedziało się aż 74\% badanych, może mieć związek z tradycyjną karierą. Tłumaczyć to jednak można dążeniem młodych ludzi do samodzielności i niezależności finansowej.

Dla celów porównawczych zaprezentowano też wyniki badania opinii studentów trzeciego roku studiów dziennych na wydziale ZIF Uniwersytetu Ekonomicznego we Wrocławiu - przedstawicieli pokolenia Y - dotyczące ich podejścia do kariery zawodowej ${ }^{15}$.

Badani studenci w większości przejawiali już nowoczesne podejście do własnej kariery zawodowej. Wskazywali na gotowość dużego zaangażowania w pracę, ale przede wszystkim taką, która naprawdę ich interesuje i daje zarazem poczucie odpowiedzialności i zadowolenia. Wymarzoną pracę określali jako taką, która wiąże się $\mathrm{z}$ nowymi wyzwaniami i jednocześnie pozwala na zachowanie równowagi praca-życie.

Jak wynika z wywiadów bezpośrednich przeprowadzonych ze studentami, wielu z nich łączyło naukę z pracą szczególnie na dalszych latach studiów (ok. 40\%). Studenci mieli bowiem świadomość, że pracodawcy mogą wyżej cenić tych, którzy już podczas studiów potrafili pogodzić naukę z pracą zawodową. Ponadto uważali, że poprzez własną aktywność zawodową nie tylko mogą zdobyć cenne doświadczenie w danej dziedzinie, ale też uzyskać wiedzę dotyczącą roli i wartości pracy w życiu. Tak więc aktywność zawodowa i społeczna dała im nie tylko konkretne umiejętności, ale też pomogła im ocenić, czego oczekują od życia i jaką ścieżkę kariery zawodowej wybrać, a także wzmocniła ich wartość na rynku pracy.

Poniżej przedstawiono także wyniki badań wskazujące na podstawowe preferencje zawodowe wśród przedstawicieli pokolenia Y, absolwentów - rok po ukończeniu przez nich studiów, opracowane na podstawie raportu dotyczącego badania losów zawodowych absolwentów Uniwersytetu Ekonomicznego we Wrocławiu ${ }^{16}$. Ogólną liczbę respondentów stanowiły 1602 osoby, które ukończyły studia w 2011 r. Na uwagę zasługuje fakt, że aktualnie aktywnych zawodowo jest już $78 \%$ badanych, natomiast $22 \%$ absolwentów nie pracuje, wśród nich prawie połowa to osoby obecnie nieszukające pracy. Jest to bardzo optymistyczny wskaźnik, biorąc pod uwagę, że bezrobocie w Polsce wśród młodych ludzi do 25. roku życia wynosi aż 27,6\% i jest znacznie wyższe niż unijna średnia wynosząca $23,5 \%{ }^{17}$.

Jak wynika z badań, dla dominującej grupy respondentów wymarzoną pracą jest objęcie stanowiska kierowniczego - 67,4\%, raczej w dużej aglomeracji oraz dalsza

\footnotetext{
${ }^{15}$ Wykorzystano tu wyniki badania opinii studentów trzeciego roku studiów dziennych na wydziale ZIF Uniwersytetu Ekonomicznego we Wrocławiu w ramach wykładu do wyboru „Organizacja i zarządzanie czasem" przeprowadzone w marcu 2012 roku (86 osób). Szerzej zob. A. Smolbik-Jęczmień, op. cit., s. 99.

${ }^{16}$ K. Pałys, M. Pałys, A. Sykuła, Kuźnia kadr IV Absolwent 2011. Raport z badania losów zawodowych absolwentów UE we Wrocławiu, Dział Obsługi Projektów Rozwojowych Uniwersytetu Ekonomicznego we Wrocławiu, Wrocław 2012

17 Podane dane pochodzą z badań Eurostatu. Szerzej zob. Rekordowe bezrobocie młodych, praca.wp.pl (dostęp: 31.05.2013).
} 
specjalizacja w wybranej dziedzinie $-62,8 \%$. Ponad połowa badanych chce pracować w młodym i dynamicznym zespole i wyżej ceni sobie rozwój zawodowy i samorealizację niż gratyfikacje finansowe (rys. 3). Ponadto badani bardzo cenią sobie możliwość pracy z doświadczonymi specjalistami - pragną w ten sposób pozyskać brakujące im doświadczenie zawodowe i wzmocnić swoją pozycję na trudnym rynku pracy. Priorytetem jest dla nich życie rodzinne (54\%), deklarują też rezygnację z elastycznego czasu pracy na rzecz pewności zatrudnienia $(56,4 \%)$, co może być jednak wynikiem wysokiego bezrobocia, szczególnie wśród absolwentów, a także dążenia do stabilizacji życiowej.

Rys. 3. Preferencje dotyczące wymarzonej pracy wśród absolwentów Uniwersytetu Ekonomicznego we Wrocławiu

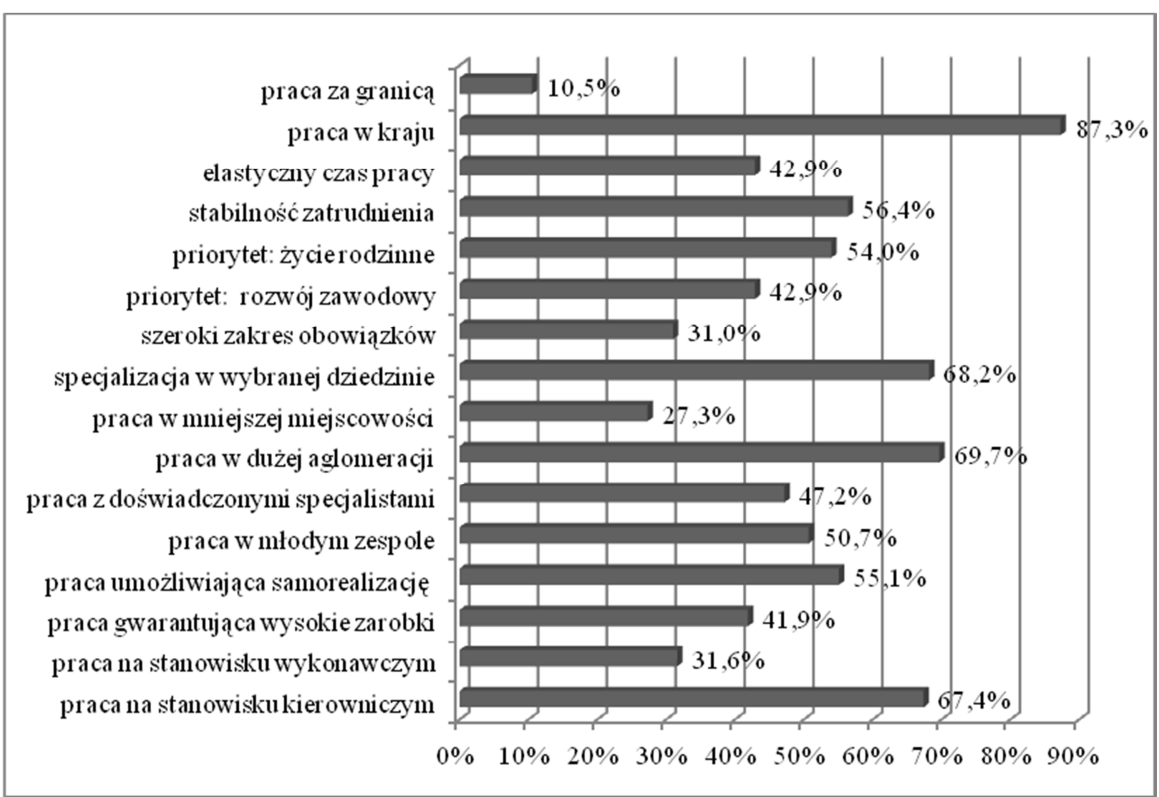

Źródło: opracowano na podstawie: K. Pałys, M. Pałys, A. Sykuła, Kuźnia kadr IV Absolwent 2011. Raport z badania losów zawodowych absolwentów UE we Wrocławiu, Dział Obsługi Projektów Rozwojowych UE we Wrocławiu, Wrocław 2012, s. 37.

Pozytywnym zjawiskiem jest też deklaracja badanych absolwentów, że chcą pracować w swoim kraju $-87,3 \%$. Jedynie co dziesiąty absolwent wskazywał na możliwość pracy za granicą. Jednakże może się to wiązać z większymi możliwościami znalezienia pracy w dużej aglomeracji, jaką jest Wrocław i cały rejon Dolnego Śląska.

\section{PODSUMOWANIE}

Współczesne kariery zawodowe w odróżnieniu od tradycyjnych charakteryzuje duży stopień nieprzewidywalności, transakcyjność i krótkoterminowość. Aktualnie zaczynają funkcjonować nowe wymiary kariery, wychodzące już poza przestrzeń organizacyjną 
jednego pracodawcy, co stwarza to duże wymagania wobec pracowników - należących zarówno do przedstawicieli pokolenia X, jak i Y.

Obecnie rozwój kariery zawodowej wymaga od wszystkich ciagłego inwestowania w siebie, uczenia się i nieustannego zdobywania nowych doświadczeń czy poszerzania posiadanych już kompetencji, aby być bardziej konkurencyjnym na trudnym rynku pracy.

Proces ten powinien być ściśle związany ze świadomym wykorzystaniem własnych zdolności, umiejętności i predyspozycji. Nie można już tylko ograniczać się do pojmowania kariery w kontekście awansu pionowego, jak w tradycyjnym podejściu do kariery - najbardziej charakterystycznym dla pokolenia X. Niezbędna staje się ustawiczna analiza otoczenia biznesowego, a wybór dalszej ścieżki edukacyjnej, profilu studiów czy też doskonalenia zawodowego powinien się opierać przede wszystkim na tym, co najprawdopodobniej będzie przydatne już w niedalekiej przyszłości.

Tak więc kształtowanie własnej kariery zawodowej nie może się ograniczać do jednorazowej decyzji dotyczącej wyboru zawodu, lecz powinno być procesem dokonującym się wraz z szeroko rozumianym rozwojem danej jednostki. Należy pamiętać, że człowiek w swoim życiu odgrywa różne role (rodzica, małżonka, dziecka, pracownika itp.), a praca zawodowa jest tylko jedną z nich.

Jak wynika $\mathrm{z}$ przeprowadzonych badań, przedstawiciele pokolenia $\mathrm{Y}$ bardziej utożsamiają się z nowoczesnym podejściem do kariery zawodowej niż przedstawiciele pokolenia X, którym jest znacznie trudniej zaadaptować się do nowych warunków funkcjonowania na rynku pracy. Młodzi ludzie wyraźniej dostrzegają potrzebę ciagłego doskonalenia się, są bardziej mobilni i otwarci na nowe wyzwania oraz wyżej cenią rozwój zawodowy i samorealizację niż gratyfikacje finansowe. Jednakże podobnie jak przedstawiciele pokolenia $X$ duże znaczenie przywiązują też do bezpieczeństwa i stabilizacji. Na pozytywną uwagę zasługuje fakt, że wszyscy są świadomi zmian dokonujących się w otoczeniu i starają się do nich przystosować na miarę swoich możliwości.

Szczególnie nowe pokolenie pracowników - pokolenie Y - już od samego rozpoczęcia swojej aktywności zawodowej musi być przygotowane na radzenie sobie z wysokim poziomem zawodowej niepewności. Wyobrażenia dotyczące wymarzonej pracy w zetknięciu z rzeczywistością są niejednokrotnie powodem rozczarowań i frustracji, szczególnie dotyczy to podjęcia pierwszej pracy zawodowej, pierwszych porażek i niepowodzeń. Ze względu na to proces kształtowania kariery zawodowej powinien podlegać ciągłym modyfikacjom, a ścieżki kariery powinny być elastyczne i dostosowane z jednej strony do potrzeb rynku, a z drugiej do oczekiwań i predyspozycji pracowników.

Istotnym warunkiem realizacji nowej kariery jest też posiadanie indywidualnej zdolności do bycia zatrudnionym na podstawie rozbudowanych kompetencji zawodowych, budowania sieci kontaktów, a także umiejętności autopromocji na zewnętrznym rynku pracy. Ponadto bardzo ważna jest spójna tożsamość profesjonalna, która wynika przede wszystkim z wcześniejszych doświadczeń zawodowych jednostki, a nie tylko z przynależności do organizacji jak w tradycyjnym modelu kariery.

Obecnie na rynku pracy rzadko zachodzi sytuacja, w której ludzie mają możliwość wykonywania jednego zawodu przez całe życie. Wymogiem czasu staje się więc ustawiczne kształcenie pracowników w celu zwiększenia ich wartości na rynku pracy i to bez względu na to, czy należą oni do pokolenia X, czy Y. Nowe wyzwania, którym muszą sprostać, to w szczególności umiejętność planowania kariery w kontekście całego 
swojego życia, adaptacyjność i elastyczność działania, duża mobilność oraz zdolność do podejmowania ryzyka.

\section{LITERATURA}

[1] Bohdziewicz P., Kariery zawodowe w gospodarce opartej na wiedzy (na przykładzie grupy zawodowej informatyków), Wydawnictwo Uniwersytetu Łódzkiego, Łódź 2008.

[2] Boni M., Raport Młodzi 2011, Wydawnictwo KPRM, Warszawa 2011.

[3] Chester E., Młodzi w pracy. Jak zadbać o pracowników pokolenia Y, Helion, Gliwice 2007.

[4] Czapiński J., Młodzi Polacy na progu dorostości - czy dadza sobie radę?, Materiały konferencyjne „Generacja Y - szansa czy konflikt”, GM Solutions, Warszawa 2012.

[5] Lanthaler W., Zugmann J., Akcja Ja, nowy sposób myślenia o karierze, Twigger, Warszawa 2000.

[6] Miś A., Koncepcja rozwoju kariery zawodowej w organizacji, UE, Kraków 2007.

[7] Molitor S.U., Strategia planowania kariery, BC Edukacja, Warszawa 2008.

[8] Lanthaler W., Zugmann J., Akcja Ja, nowy sposób myślenia o karierze, Twigger, Warszawa 2000.

[9] Pałys K., Pałys M., Sykuła A., Kuźnia kadr IV Absolwent 2011. Raport z badania losów zawodowych absolwentów UE we Wrocławiu, Dział Obsługi Projektów Rozwojowych Uniwersytetu Ekonomicznego we Wrocławiu, Wrocław 2012.

[10] Rekordowe bezrobocie młodych, praca.wp.pl (dostęp: 31.05.2013).

[11] Rybak M., Kariery bez granic. Nowe spojrzenie na kariere zawodowa, [w:] Zarzadzanie zasobami ludzkimi w przedsiębiorstwie, red. M. Rybak, Wydawnictwo SGH, Warszawa 1998.

[12] Smolbik-Jęczmień A., Nowe trendy w podejściu do kariery zawodowej wśród przedstawicieli pokolenia Y, [w:] Osobowościowe i kompetencyjne uwarunkowania sukcesu, red. A. Barabasz, E. Głuszek, Prace Naukowe Uniwersytetu Ekonomicznego we Wrocławiu, Wrocław 2012/273.

[13] Weroniczak L., Człowiek $w$ obliczu szybko dokonujacych się zmian, [w:] Bo życie to nieustanny rozwój. Poradnik, red. J. Majerowska, Edustacja.pl, Poznań 2010.

[14] Zagórowska A., Konflikt generacyjny wokót pracy, [w:] Perspektywy mtodzieży. Mtodzież w perspektywie. Region - Polska - Europa - Świat. Część I. Młodzież a edukacja i rynek pracy, red. A. Zagórowska, Wydawnictwo Politechnika Opolska, Opole 2012.

\section{DEVELOPMENT OF PROFESSIONAL CAREER AMONG THE REPRESENTATIVES OF GENERATION X AND Y - NEW CHALLENGES}

Dynamic changes which we could observe ina labor market and accompanying them changes in employment structure - disappearing old professions and arising new ones constitute new challenges in shaping the professional career both for employees and employers. The traditional model of professional career often understood as job for life belong to the past and the requirement of the time become constantly learning and vocational retraining in order to build the career capital and increasing the individual ability to be employed.

Nowadays, the professional career leads the trend of lifelong learning and development. It requires new approach to professional career as a life project and determines creating conditions, in which each person will have an easy access to solid information about labour market. Furthermore, in the labour market it is observed great diversity of age group of employees, which has an impact on generation differences, it appears also in evidence of their behavior both towards work and professional career. 
The aim of this article is to present new challenges in approach to professional career among the representatives of generation $\mathrm{X}$ and $\mathrm{Y}$ (generation $\mathrm{X}$ - people who were born in 1965-1980, and generation $Y$ - young people who were born after 1980).

In the article it is concluded the results presentation of research and opinions of employers from Lower Silesia companies (representatives of generation X and Y), students and graduates from University of Economics in Wroclaw (representatives of generation Y) concerning presented issue.

Keywords: professional career, new challenges, generation $\mathrm{X}$ and $\mathrm{Y}$, expectations of the job, survey

\section{DOI: 10.7862/rz.2013.mmr.54}

Tekst złożono w redakcji: wrzesień 2013

Przyjęto do druku: grudzień 2013 